\title{
Laser Microdissection Reveals That Transcripts for Five Plant and One Fungal Phosphate Transporter Genes Are Contemporaneously Present in Arbusculated Cells
}

\author{
Raffaella Balestrini, Jorge Gómez-Ariza, Luisa Lanfranco, and Paola Bonfante \\ Istituto Protezione Piante, CNR and Dipartimento di Biologia Vegetale, Università di Torino, Viale Mattioli, 25-10125 Torino, \\ Italy
}

Submitted 16 February 2007. Accepted 23 April 2007.

\begin{abstract}
The establishment of a symbiotic interaction between plant roots and arbuscular mycorrhizal (AM) fungi requires both partners to undergo significant morphological and physiological modifications which eventually lead to reciprocal beneficial effects. Extensive changes in gene expression profiles recently have been described in transcriptomic studies that have analyzed the whole mycorrhizal root. However, because root colonization by AM fungi involves different cell types, a cell-specific gene expression pattern is likely to occur. We have applied the laser microdissection (LMD) technology to investigate expression profiles of both plant and fungal genes in Lycopersicon esculentum roots colonized by Glomus mosseae. A protocol to harvest arbuscule-containing cells from paraffin sections of mycorrhizal roots has been developed using a Leica AS LMD system. RNA of satisfactory quantity and quality has been extracted for molecular analysis. Transcripts for plant phosphate transporters $(L e P T s)$, selected as molecular markers for a functional symbiosis, have been detected by reverse-transcriptase polymerase chain reaction assays and associated to distinct cell types, leading to novel insights into the distribution of $L e P T$ mRNAs. In fact, the transcripts of the five phosphate transporters (PTs) have been detected contemporaneously in the same arbusculated cell population, unlike from the neighboring noncolonized cells. In addition, fungal $\mathrm{H}^{+}$ATPase (GmHA5) and phosphate transporter (GmosPT) mRNAs were found exclusively in arbusculated cells. The discovery that five plant and one fungal PT genes are consistently expressed inside the arbusculated cells provides a new scenario for plant-fungus nutrient exchanges.
\end{abstract}

Additional keywords: AM symbiosis, tomato.

Arbuscular mycorrhizas (AMs), formed between AM fungi and vascular plants, are widespread mutualistic symbiosis where fungi colonize root cells, transferring mineral nutrients (mainly phosphate) and, in turn, obtaining carbon of photosynthetic origin (Harrison 1999). The root colonization process occurs in sequential steps that involve both the epidermal and

Corresponding author: Paola Bonfante; Telephone: +00390116502927; Fax: +00390116705962; E-mail: p.bonfante@ipp.cnr.it

*The $\boldsymbol{e}$-Xtra logo stands for "electronic extra" and indicates that Figure 5 appears in color online. cortical cells, where the fungus develops inter- and intracellular hyphae, coils, and arbuscules, according to a pattern that can be influenced by both partners (Genre and Bonfante 2005). Morphological observations have shown that dramatic changes take place in the structure of host cells upon fungal colonization, because a symbiotic interface is created by the proliferation of a host membrane around the fungus and the deposition of a thin apoplastic layer containing molecules which are common to the plant's primary wall (Balestrini and Bonfante 2005; Bonfante 2001). In spite of the structural similarities of plantfungus contact in epidermal and cortical cells, the nutritional exchanges usually are expected to be confined to the inner cortical cells, where branched arbuscules develop (Bucher 2007; Harrison 2005; Reinhardt 2007).

Mycorrhizal development is triggered by numerous cellular processes, is accompanied by mycorrhiza-specific gene expression, and probably reflects the presence of cell autonomous signals as well as of mobile signals operating in the root cortex (Balestrini and Lanfranco 2006; Harrison 2005; Reinhardt 2007). Many recent studies aimed at investigating the global transcript and protein profiling of mycorrhizal roots have revealed changes in the metabolic pathways that control nutritional exchanges (Güimil et al. 2005; Hohnjec et al. 2005; Liu et al. 2003). However, the development of symbiosis is not a synchronous process and, after an initial colonization of the root cortex, secondary infection events commence and the invasion process is reiterated. As a consequence, this raises the question of whether the use of whole organs can mask celltype-specific differences in RNA or protein levels and suggests that efficient methods for routinely isolating populations of specific cell types are needed.

Laser microdissection (LMD), which has been used widely by animal biologists to study gene expression in specific cell types and to elucidate the associated molecular events, recently has been adapted to plant tissues (Day et al. 2005). Protocols have been optimized and applied to several plant species, and methods developed for the identification of differentially expressed transcripts have been applied to LMD-derived RNA (Day et al. 2005, 2006; Nelson et al. 2006).

Phosphate uptake, transfer, and delivery already have been investigated in depth in mycorrhizal systems (Bucher 2007; Javot et al. 2007a; Karandashov and Bucher 2005; Smith et al. 2003); therefore, we selected molecular markers from such crucial processes to verify a cell-specific gene expression pattern during mycorrhizal interactions and the reliability of LMD technology for plant-fungus interactions. 
In AM symbiosis, the key functional benefit to the plant is the supply of phosphate (Pi). Mycorrhizal plants can acquire $\mathrm{Pi}$ directly from the soil through plant-specific phosphate transporters (PTs) (the direct uptake pathway) or through uptake and transport systems of the fungal symbiont (the mycorrhizal uptake pathway). It has been demonstrated that, in most cases, there is a preferential uptake via fungal hyphae (Smith et al. 2003) and that the Pi eventually is delivered by the arbuscules to the cortical cells. These cells are particularly efficient in Pi uptake, thanks to the induction of mycorrhiza-specific PTs (Bucher 2007). However, common parameters, such as plant growth responses and $\mathrm{P}$ content, do not always directly correlate to the extent of the contribution of Pi uptake exerted by the fungus. There is clear evidence of functional diversity in different AM fungus-plant combinations. Thus, the study of plant PTs and of their functioning represents a key point to fully understand this process. In recent years, several PT genes from different plants have been described and their expression has been characterized in mycorrhizal roots with the identification of mycorrhizal specific PTs (Glassop et al. 2005; Harrison et al. 2002; Karandashov and Bucher 2005; Nagy et al. 2005; Paszkowski et al. 2002; Raush et al. 2001). On these bases, plant PTs currently are considered functional symbiosis markers. Sequences have been described in Lycopersicon esculentum for five PT genes (Nagy et al. 2005) and the spatial distribution of their transcripts already has been investigated for some of them (Damar et al. 1998; Liu et al. 1998; Nagy et al. 2005; Rosewarne et al. 1999).

Here, we report a protocol to harvest cortical cells from paraffin sections of Glomus mosseae-tomato roots using a Leica LMD system. Transcripts for plant PTs genes have been detected and associated to arbusculated and noncolonized cortical cells by means of reverse-transcriptase polymerase chain reaction (RT-PCR) assays. The approach allowed us to detect that arbuscule-containing cells contain all five plant PT gene transcripts, in addition to fungal $\mathrm{H}^{+}$ATPase and phosphate transporter mRNAs.
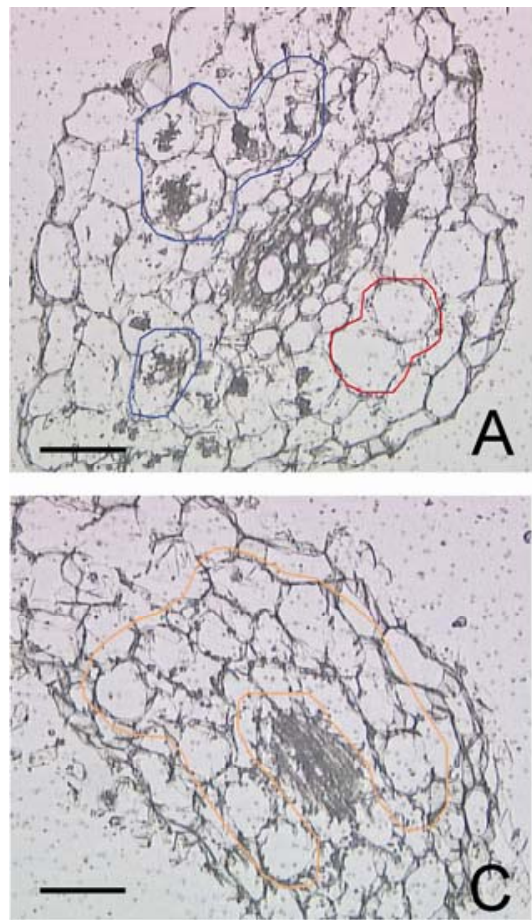

\section{RESULTS}

\section{Morphology preservation of paraffin sections and RNA yield.}

In order to set up a protocol for the analysis of cell-typespecific gene expression in AMs, the LMD technology was applied to tomato roots colonized by the AM fungus $G$. mosseae. The use of paraffin tissue preparation coupled to Methacarn fixation provided root tissues with a preservation level that is sufficiently good to distinguish specific cell types in both nonmycorrhizal and mycorrhizal roots. Arbusculated cells in particular were easily distinguishable (Fig. 1). For further analyses, three cell populations were considered: cortical cells from nonmycorrhizal roots $(\mathrm{C})$, noncolonized cortical cells from mycorrhizal roots (NMyc), and arbusculated cells (Myc) (Fig. 1). From 3,000 to 11,000 cells of each cell population were collected and processed for RNA extraction. The NanoDrop quantification showed a yield of 18 to $170 \mathrm{ng}$, depending on the samples and number of cells (Table 1).

Detection of plant mRNAs in microdissected samples.

All RNA samples were checked for DNA contamination by RT-PCR analyses conducted with specific ribosomal primers for

Table 1. RNA yield evaluated with a NanoDrop 1000 spectrophotometer

\begin{tabular}{lcc}
\hline Populations & RNA yield $(\mathbf{n g})$ & RNA $(\mathbf{n g} / \mathbf{\mu l})$ \\
\hline First biological replicate & & \\
C $(\approx 3,000$ cells $)$ & 59.2 & 3.70 \\
NMyc $(\approx 3,000$ cells $)$ & 48.5 & 3.03 \\
Myc $(\approx 3,000$ cells $)$ & 18.4 & 1.15 \\
Second biological replicate & & \\
C $(\approx 11,000$ cells $)$ & 169.7 & 8.08 \\
NMyc $(\approx 6,000$ cells $)$ & 120.33 & 5.73 \\
Myc $(\approx 6,700$ cells $)$ & 130 & 6.19 \\
\hline a $C=$ cortical cells from nonmycorrhizal roots, NMyc $=$ noncolonized \\
\multicolumn{2}{c}{ cortical cells from mycorrhizal roots, and Myc $=$ arbusculated cells. }
\end{tabular}
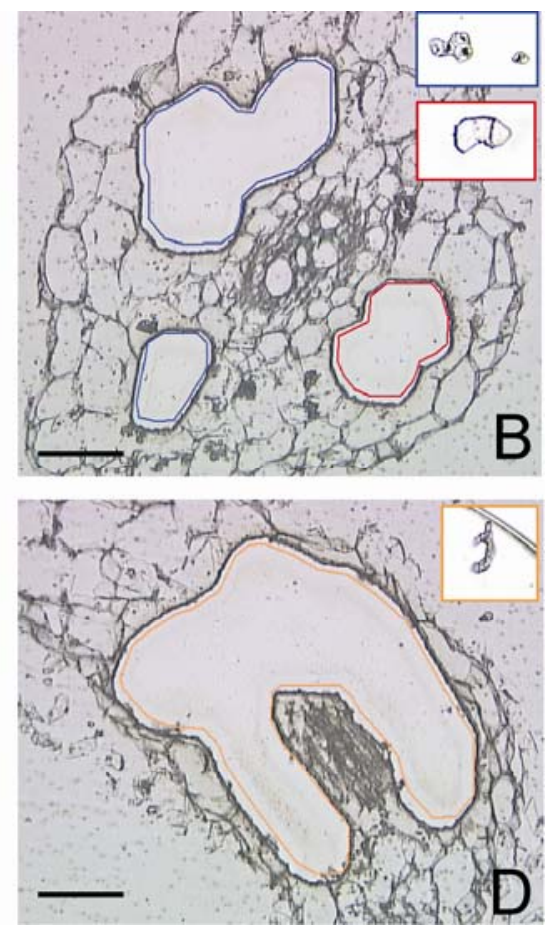

Fig. 1. Laser microdissection of root cortical cells from $\mathbf{A}$ and $\mathbf{B}$, mycorrhizal (Myc) and $\mathbf{C}$ and $\mathbf{D}$, nonmycorrhizal (NMyc) roots. Microdissection of Myc (selected with a blue circle) and NMyc cells (selected with a red circle) A, before laser and $\mathbf{B}$, tissue remaining after cutting; blue inset, collected Myc cells; red inset, collected NMyc cells. Cutting of cortical cells (C) from nonmycorrhizal roots $\mathbf{C}$, before laser and $\mathbf{D}$, tissue remaining after cutting; inset, collected cells. Bars, $50 \mu \mathrm{m}$.

1056 / Molecular Plant-Microbe Interactions 
tomato $18 S$ rRNA (Table 2). A PCR product of the expected size (400 bp) was obtained in all the RNA samples: cortical cells from nonmycorrhizal roots (C), noncolonized cortical cells from mycorrhizal roots (NMyc), and arbuscule-containing cells (Myc) (Fig. 2). The absence of an amplified product in RT-negative reactions excluded any DNA contamination (Fig. 2).

PTs are considered markers of a functional AM symbiosis, and mycorrhizal-specific genes have been described in several plant species (Bucher 2007). In order to detect specific PT transcripts in RNAs from microdissected cells by means of RT-PCR assays, oligonucleotides were designed to specifically amplify each of the five PT sequences described in tomato thus far (Table 2) (Nagy et al. 2005). Primers first were tested on plant and fungal genomic DNA in order to verify their specificity. All the primers gave an amplified fragment of the

Table 2. Primers, annealing temperature $\left(\mathrm{T}_{\mathrm{a}}\right)$, and length of the amplified DNA fragment ${ }^{\mathrm{a}}$

\begin{tabular}{llcc}
\hline Primers & \multicolumn{1}{c}{ Sequence } & T $_{\mathbf{a}}\left({ }^{\circ} \mathbf{C}\right)$ & $\begin{array}{c}\text { Length } \\
(\mathbf{b p})\end{array}$ \\
\hline 18S For & AAAAGGTCGACGCGGGCT & $\ldots$ & $\ldots$ \\
18S Rev & CGACAGAAGGGACGAGAC & 58 & 400 \\
PT1 For & CATTGTTTCTGCAGCATTCAAGG & $\ldots$ & $\ldots$ \\
PT1Rev & GGCTCCTTTGCTTCAGAAATAGCTG & 55 & 292 \\
PT2 For & GATTCGATCACGCGTATAGATCC & $\ldots$ & $\ldots$ \\
PT2 Rev & GAAATTTGTTCGATTTTGGCTTCC & 55 & 262 \\
PT3 For & TCAATCTACTGATCCATCTAAAGTC & $\ldots$ & $\ldots$ \\
PT3 Rev & TAGTTTGTCATTTCCCCTTAG & 55 & 206 \\
PT4For & GAAGGGGAGCCATTTAATGTGG & $\ldots$ & $\ldots$ \\
PT4Rev & ATCGCGGCTTGTTTAGCATTTCC & 55 & 182 \\
PT4For & GAAGGGGAGCCATTTAATGTGG & $\ldots$ & $\ldots$ \\
PT4Rev4 & TCGTATTTGACTCCAATGATCGC & 55 & 596 \\
PT4For & GAAGGGGAGCCATTTAATGTGG & $\ldots$ & $\ldots$ \\
PT4Rev5 & TTACCAGAAGCTGCGCTCAACG & 55 & 761 \\
PT5For & CACTGCCATTATTGAAGGAAATG & $\ldots$ & $\ldots$ \\
PT5Rev & CTAACAAGTCCCATGGTCGG & 55 & 258 \\
NDL22 & CCTTTTGAGCTCGGTCTCGTG & $\ldots$ & $\ldots$ \\
5.21 & TGGTCCGTGTTCAAGACG & 65 & 380 \\
HA5 For & GTACTTTATTAACTGTGGCTTC & $\ldots$ & $\ldots$ \\
HA5 Rev & ATATCCCGAAAGACGTGTCG & 55 & 150 \\
PMA1 For & TTGGCCAAAAGAGGTTTACG & $\ldots$ & $\ldots$ \\
PMA1 Rev & GCAATGTTCCGTGATCTCCT & 55 & 288 \\
GmPT For & ACTGTTGGCGCTTAGTGCTTGG & $\ldots$ & $\ldots$ \\
GmPT Rev & CAGCCCAACTTGATTTTGGTACG & 60 & 222 \\
\hline
\end{tabular}

${ }^{a}$ The Glomus mosseae 28S rDNA primers (NDL22 and 5.21) were described by van Tuinen and associates (1998). Primers were complementary, respectively, to positions 700 to 722 and 991 to 965 for LePT1 (AF028873); 618 to 640 and 879 to 856 for LePT2 (AF022874); 1,383 to 1,407 and 1,588 to 1,565 for LePT3 (AY804011); 1,425 to 1,446 and 1,606 to $1584,2,020$ to $1,998,2,185$ to 2,164 for LePT4 (AY885651); and 147 to 169 and 404 to 385 for LePT5 (AY885653). expected size from the plant DNA and no band from fungal DNA (data not shown). The PCR products for the different PT genes were purified and sequenced. Blastn analyses confirmed their identity and, therefore, the specificity of the primers.

RT-PCR reactions on microdissected samples highlighted the presence of $L e P T 1$ and $L e P T 2$ transcripts in all the cell populations (Fig. 3A and B). On the other hand, the LePT3 and LePT4 mRNAs were detected exclusively in arbusculecontaining cells (Fig. 3C and 3E). An amplified fragment corresponding to LePT5 was observed in arbuscule-containing cells as well as in noncolonized cells from the same section (Fig. 3D).

The length of the amplifiable RT-PCR products was assessed by using LePT4 primers pairs leading to longer PCR fragments (Table 2). Amplified fragments of 550 and $750 \mathrm{bp}$ were obtained from the arbuscule-containing cells (Fig. 3F and 3G), although the signal intensity was weak for the longest PCR product.

\section{Detection of fungal mRNAs in microdissected samples.}

The RNA preparations were amplified by RT-PCR assays using primers specific for $G$. mosseae to investigate whether fungal transcripts could be detected (Table 2). No cross-hybridization on the plant genomic DNA was observed (data not shown). A band of the expected size $(380 \mathrm{bp})$ was found, using ribosomal $28 \mathrm{~S}$ rDNA primers, in both samples collected from mycorrhizal roots (Fig. 4A); that is, not only in arbuscule-containing cells but also in the NMyc cell population. This result could be explained by the presence of fungal structures, probably thin (inter- or intracellular) hyphae within the $10-\mu \mathrm{m}$ thickness of the section, but not visible at microscopic inspection. Instead, arbuscules generally were easily seen on sections because they fill the whole host cell lumen.

Two G. mosseae $\mathrm{H}^{+}$ATPases genes (GmHA5 and GmPMAl) and a PT gene $(G m o s P T)$ were investigated to check the viability of the fungal structures and their potential role in the nutrient exchanges because they already have been reported in literature as expressed during the intraradical symbiotic phase (Benedetto et al. 2005; Requena et al. 2003). The results confirmed the presence of the transcripts, corresponding to the GmHA5 and the GmosPT genes, exclusively in arbuscule-containing cells (Fig. 4B and C), whereas no signal corresponding to the GmPMAl gene was obtained (data not shown).

\section{DISCUSSION}

The asynchronous and reiterated colonization process of roots by AM fungi originates a heterogeneous cell environment: adjacent epidermal and cortical cells can experience different types of interaction with fungal signals or structures,

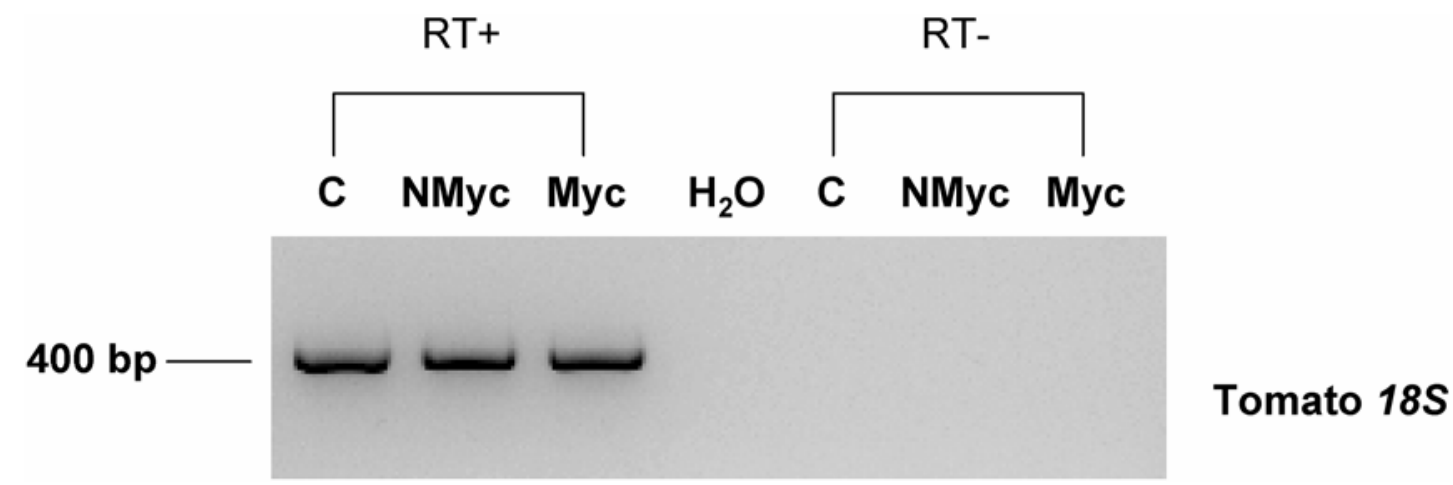

Fig. 2. Reverse-transcriptase (RT) polymerase chain reaction analysis of microdissected cells with tomato ribosomal primers. An amplified fragment of the expected size is present in all the samples. The absence of an amplified product in RT-negative reactions excludes any DNA contamination. C, cortical cells from non-mycorrhizal roots; NMyc, noncolonized cortical cells from mycorrhizal roots; Myc, arbusculated cortical cells. 
which may trigger the activation of distinct responses. Thus, characteristic expression profiles can occur in very close cell types. LMD currently is one of the most powerful tools available to investigate expression patterns associated to distinct cell types and, therefore, is an ideal instrument for the study of cell complexity in AM symbiosis.

Genes for plant PT have been used as molecular markers to assess the reliability of an LMD protocol to describe cell-typespecific gene expression in mycorrhizal roots, because they have been investigated in depth (Bucher 2007). Tomato was selected as the host plant because five genes have been described already and spatial expression data already were available for some of these genes (Liu et al. 1998; Nagy et al. 2005; Rosewarne et al. 1999). Our results provide the new information that the mRNAs corresponding to the five PT genes are differently associated to distinct cell types during the interaction between tomato and $G$. mosseae. In fact, they demonstrate that the cortical cells from the control roots exclusively contain LePT1 and LePT2 transcripts, unlike the mycorrhizal roots, where the noncolonized cortical cells also accumulate LePT5 mRNA and the arbusculated cells activate the whole set of five PT genes, adding LePT3 and LePT4 transcripts to the previous ones (Fig. 5).

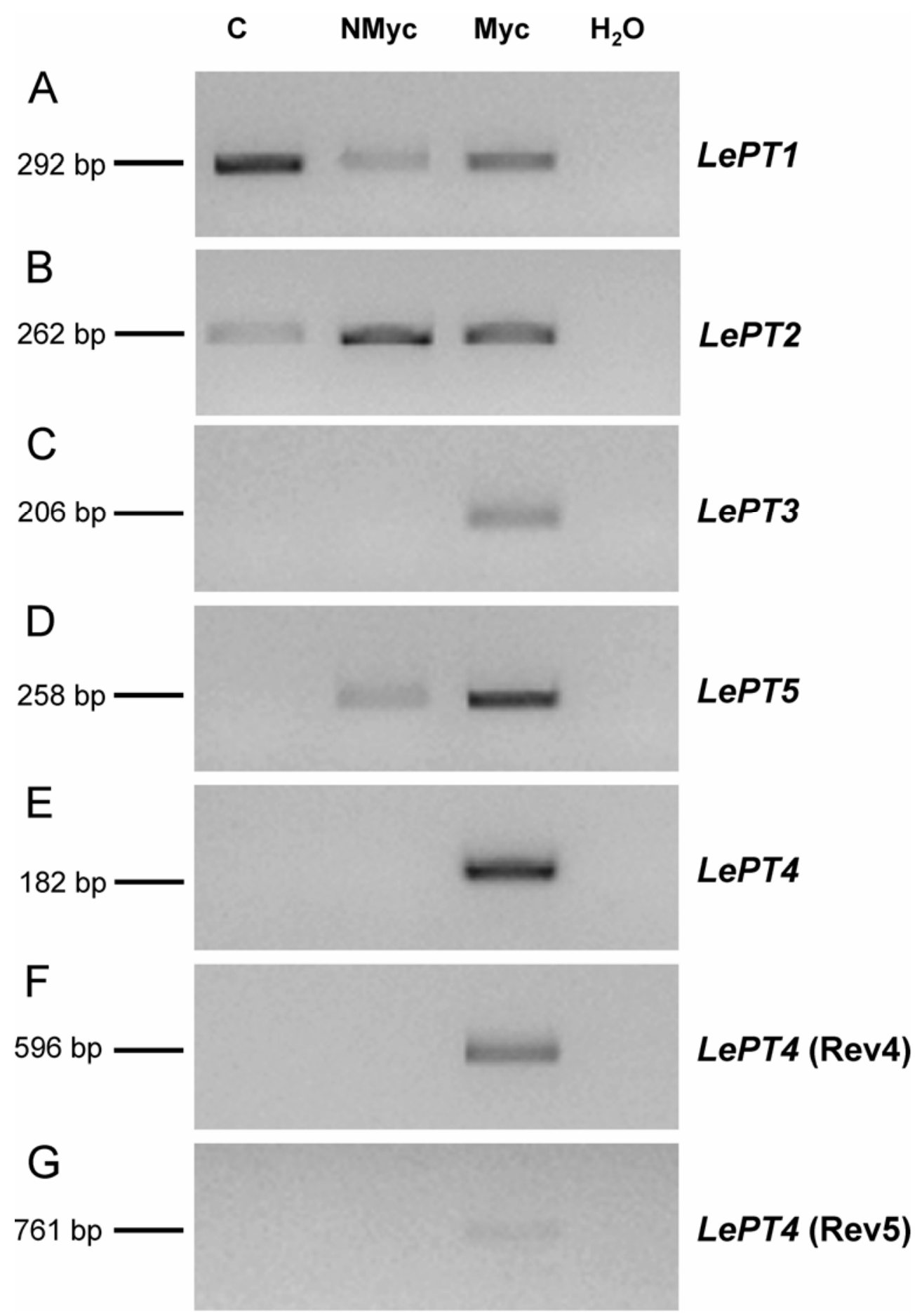

Fig. 3. Reverse-transcriptase polymerase chain reaction analysis of microdissected cells with specific primers for five tomato LePT genes. Identification of the amplified fragments in the different cell populations. C, cortical cells from nonmycorrhizal roots; NMyc, noncolonized cortical cells from mycorrhizal roots; Myc, arbusculated cortical cells. 
LePT1 and LePT2 genes were found expressed in cortical cells in both the absence and the presence of the AM fungus, indicating that they are constitutively expressed in cortical cells independently of the fungal signals. This result confirms previous data obtained from RT-PCR assays using RNA extractions from whole roots (Nagy et al. 2005).

Previous in situ hybridization experiments showed the presence of LePT1 and LePT2 transcripts in nonmycorrhizal and

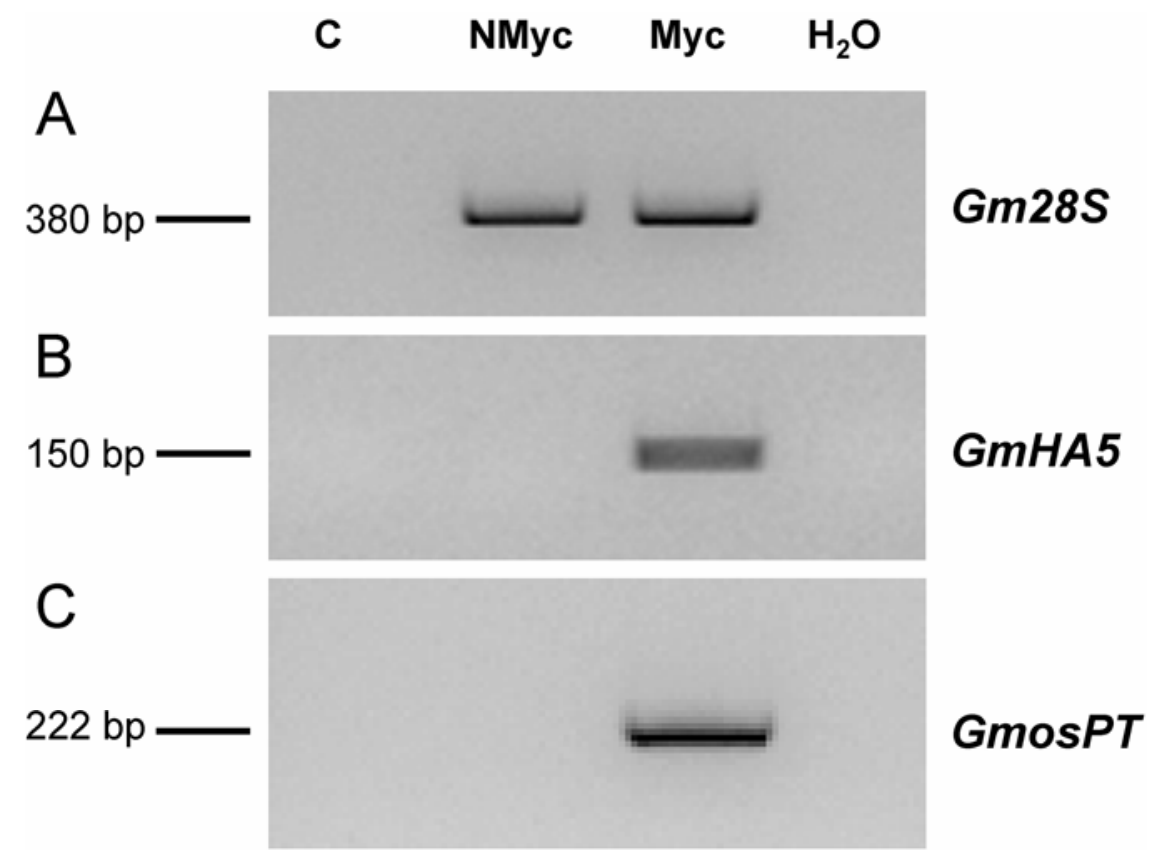

Fig. 4. Reverse-transcriptase polymerase chain reaction analysis of microdissected cells with A, Glomus mosseae ribosomal primers, B, specific primers for the GmHA5, and C, GmosPT genes. A, Fungal transcripts are present both in the noncolonized cortical cells from mycorrhizal roots (NMyc) and arbusculated cortical cells (Myc) cell populations. B, An amplified fragment corresponding to GmHA5 transcripts is evident only in Myc cells. C, An amplified fragment corresponding to GmosPT transcripts is evident only in the Myc cell population. $\mathrm{C}=$ cortical cells from nonmycorrhizal roots.

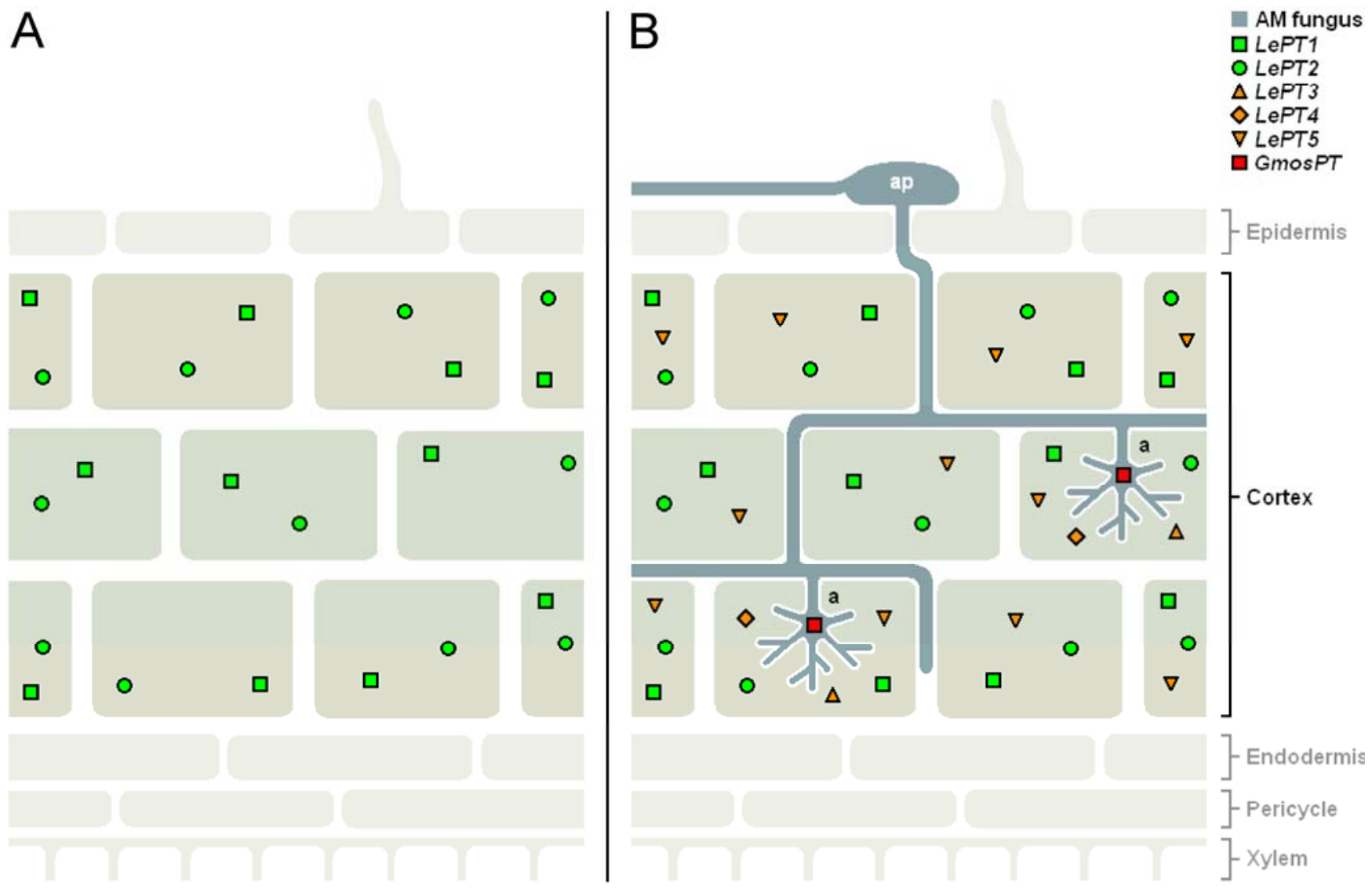

Fig. 5. Schematic view of plant and fungal phosphate transporter transcripts distribution in root cortical cells. A, Nonmycorrhizal root. B, Mycorrhizal root with arbusculated cells (a); ap = appressorium. 
mycorrhizal roots, although the signal associated to cortical cells was very faint (Damar et al. 1998; Liu et al. 1998; Rosewarne et al. 1999). Therefore, RT-PCR assays coupled to LMD seem to be more a sensitive approach than nonradioactive in situ hybridizations. As far as the well-characterized mycorrhiza-specific LePT4 is concerned, our results confirm that its spatial expression pattern is confined exclusively to the colonized cells of mycorrhizal roots, as described in Nagy and associates (2005). We observed a similar expression profile for LePT3. On the other hand, LePT5 mRNA was detected in both colonized and noncolonized cells from mycorrhizal roots. No information has been available thus far concerning LePT3 or LePT5 mRNA spatial distributions, because they were described as mycorrhiza-specific on the basis of RT-PCR or Northern blot assays performed on bulk sampling (Nagy et al. 2005).

The expression profiles obtained from LMD mycorrhizal samples confirm that LePT3, LePT4, and LePT5 are activated upon root colonization by an AM fungus and suggest that LePT5 undergoes a gene expression regulation that is different from LePT4 or LePT3. An explanation of LePT5 expression profile is supported by results obtained on the fungal RNA. Investigations using fungal ribosomal primers allowed us to verify the presence of fungal transcripts not only in arbusculecontaining cells but also in cells from the same root that were expected to be noncolonized under microscopic inspection. The presence of fungal structures that are different from arbuscules may be sufficient to trigger LePT5 gene expression activation. As an alternative, LePT5 could be regulated by mobile signals. Increasing evidence exist that fungal signals can affect plant gene expression even in the absence of physical contact (Kosuta et al. 2003; Navazio et al. 2007) or intracellular colonization (Genre et al. 2005).

Two $\mathrm{H}^{+}$-ATPases (GmHA5 and GmPMAl) were selected for the detection of fungal transcripts of protein coding genes, because they play a key role in establishing the electrochemical gradient required for the transfer of nutrients (phosphate or carbon) at the symbiotic interface (Gianinazzi-Pearson et al. 1991; Requena et al. 2003; Smith and Smith 1990). Interestingly, our results indicate that GmHA5 expression is limited to arbusculated cells, suggesting that its gene product may provide energy for nutrient uptake by the arbuscule. The GmPMAl transcripts were not detectable, which would suggest a low abundance of mRNAs or their absence, and this is in agreement with previous RT-PCR analyses on whole roots which showed GmHA5 as upregulated during the symbiotic phase and GmPMAl as preferentially expressed during asymbiotic growth (Requena et al. 2003). In addition, the presence of GmosPT transcripts in the arbusculated cells gives a sound confirmation to the results shown by Benedetto and associates (2005) on the whole mycorrhizal root. Differently from the current models, where the fungal transcripts are located in extraradical hyphae (Bucher 2007; Javot et al. 2007a), our results indicate that, in this cell population, both the partners express PTs. The efflux of phosphate probably is occurring in competition with its uptake and so that the fungus might exert a control over the amount of phosphate delivered to the plant. The discovery that five plant and one fungal PT genes are consistently expressed inside the arbusculated cells provides a new scenario for the plant-fungus nutrient exchanges.

In conclusion, to our knowledge, this is the first report that has showed that LMD can be applied successfully to AM roots, because this technology allowed us to localize both plant and fungal gene expression in distinct homogeneous root cell populations. Therefore, plant-microbe interactions seem to be a field where LMD could be expected to have a strong impact, because it would allow the collection of cells at different stages of the infection process (Ramsay et al. 2006; Tang et al. 2006).
As a second and more relevant point, our results lead to new information concerning tomato PT gene expression in mycorrhizal roots. Arbuscule-containing cells were shown to contemporaneously contain the transcripts of all five PT genes. Among the myc-specific genes, LePT3 and LePT4 showed a similar cell-type expression pattern, whereas the myc-specific induction of LePT5 seems not to be closely dependent on a massive intracellular colonization by the AM fungus.

Due to the crucial role of $\mathrm{P}$ in their nutrition, plants seem to guarantee this function through the functional redundancy of a gene family. The contemporaneous presence of five PT mRNAs in the arbuscule-containing cells strongly suggests that the symbiosis enhances plant Pi uptake capabilities by recruiting additional PTs in this cell population. These mycorrhizal-induced PTs may represent the added value given by the AM symbiosis to the plant partner. An indirect experimental confirmation of this speculation comes from the observation that the knock-out of a mycorrhizal-inducible PT gene also leads to the reduction of the fungal colonization (Javot et al. 2007b; Maeda et al. 2006).

It would be interesting to investigate whether the presence of five mRNAs mirrors a differential localization of PT proteins along the plasma membrane of a single arbusculated cell. We hypothesize an asymmetric distribution of PTs: the myc-specific transporters could be associated to the periarbuscular membrane, as already demonstrated for MtPT4 (Harrison et al. 2002), while the constitutively expressed LePT1 and LePT2 could be confined to the peripherical plasma membrane.

\section{MATERIALS AND METHODS}

\section{Plant material.}

L. esculentum L. cv. Moneymaker seed were surface sterilized with a 3-min wash in $70 \%$ ethanol with four drops of Tween 20 and a 13-min wash in 5\% sodium hypochlorite and rinsed three times for $10 \mathrm{~min}$ each in distillated water. After the sterilization, seeds were placed in a petri dish with $0.6 \%$ agar and $\mathrm{H}_{2} \mathrm{O}$, kept in the dark for 5 days, and then placed in the light for 4 days. The seedlings were placed in a pot with a mixture of quartz sand and an inoculum made up of mycorrhized root pieces, spores, and mycelium of the AM fungus Glomus mosseae (T. H. Nicolson \& Gerd.) Gerd. \& Trappe BEG12 (Biorize, Bretenière, France). The inoculum/sand ratio was 3:10. The plants were sampled after 2 months. All plants were watered once a week with a low-phosphate $\left(3.2 \mu \mathrm{M} \mathrm{Na}_{2} \mathrm{HPO}_{4}\right)$ Long Ashton solution (Hewitt 1966), twice a week with water, and kept in a growth chamber for approximately 2 months with a photoperiod of $16 \mathrm{~h}$ of light and $8 \mathrm{~h}$ of darkness at 23 and $21^{\circ} \mathrm{C}$, respectively. Mycorrhization levels were estimated using the method described by Trouvelot and associates (1986): the roots presented a good percentage of colonization, where frequency of mycorrhization of root fragments $(\mathrm{F})=$ $55 \%$, intensity of root cortex colonization $(\mathrm{M})=15 \%$, average presence of arbuscules within the infected areas (a) $=99 \%$, and arbuscule abundance in the root system $(\mathrm{A})=14 \%$.

\section{Tissue preparation.}

Mycorrhizal and nonmycorrhizal roots (dissected into 5- to $10-\mathrm{mm}$ segments with a razor blade in the freshly prepared fixative) were fixed in freshly prepared Methacarn (absolute methanol/chloroform/glacial acetic acid 6:3:1) at $4^{\circ} \mathrm{C}$ overnight for paraffin embedding (Inada and Wildemurth 2005; Jiang et al. 2006). The tissues subsequently were dehydrated in a graded series of ethanol $(50,70$, and $90 \%$ in sterilized water and $100 \%$ twice), followed by isopropanol (twice), with each step on ice for $1 \mathrm{~h}$. The isopropanol was replaced gradually with paraffin (Paraplast Plus; Sigma-Aldrich, St Louis). In de- 
tail, a few chips of Paraplast Plus (approximately 10 pieces) were added to $20 \mathrm{ml}$ of isopropanol. Once the chips dissolved at $50^{\circ} \mathrm{C}$ overnight, this mixture was substituted with molten Paraplast Plus at $60^{\circ} \mathrm{C}$ and the medium was replaced at approximately 6-h intervals (four to five changes of paraffin all together), then embedded in paraffin. In the first step with pure paraffin, tubes were open to evaporate traces of isopropanol. Leica RNase-free PEN-foil slides were used for LMD. Sections of $10-\mu \mathrm{m}$ thickness were cut using a rotary microtome, and the ribbons were placed and stretched out on the slides with diethylpyrocarbonate (DEPC)-treated double-distilled (dd) $\mathrm{H}_{2} \mathrm{O}$ on a $40^{\circ} \mathrm{C}$ warming plate. The sections were dried in a $40^{\circ} \mathrm{C}$ oven, stored at $4{ }^{\circ} \mathrm{C}$, and used within 2 days.

\section{LMD.}

A Leica AS Laser Microdissection system (Leica Microsystems, Inc., Bensheim, Germany) was used to isolate cells from the prepared tissue sections. Just before use, the paraffin sections were deparaffinized in a neoclear (Merck, Darmstadt, Germany) treatment, for $10 \mathrm{~min}$, in $100 \%$ ethanol for $2 \mathrm{~min}$, and then air dried. The deparaffinized slides were placed face down on the microscope. The tissues were visualized on a computer monitor through a video camera. The selected cells were encircled on the computer screen using a mouse, and then cut using a UV laser (337-nm wavelength). Care was taken to direct the laser to ablate the cells surrounding the selected cells, therefore preserving their integrity. The dissection conditions were optimized to obtain a clean, narrow excision of the selected cells: 40-XT objective at power 35 to 45 and speed 3 to 4 . The cells subsequently fell into the $0.5-\mathrm{ml}$ RNase-free PCR tube caps located beneath the visualized tissue section.

On average, approximately 1,500 to 5,000 cell sections were collected in a tube per day. After collection, approximately 25 $\mu l$ of RNA extraction buffer from the PicoPure kit (Arcturus Engineering, Mountain View, CA, U.S.A.) was added. Samples were incubated at $42^{\circ} \mathrm{C}$ for $30 \mathrm{~min}$, centrifuged at $800 \times g$ for $2 \mathrm{~min}$, and stored at $-80^{\circ} \mathrm{C}$. Then, for the following steps of RNA extraction, cells were pooled in a single tube with a final volume of $50 \mu \mathrm{l}$.

\section{RNA extraction.}

RNA extractions were performed with a slightly modified PicoPure kit protocol (Arcturus Engineering). A DNase treatment was not performed on the kit column. The RNA was eluted in 25 to $30 \mu \mathrm{l}$ of DEPC $\mathrm{ddH}_{2} \mathrm{O}$ and treated with RNasefree DNase (Promega Corp., Madison, WI, U.S.A.) following the manufacturer's instruction. After precipitation using $\mathrm{Na}$ acetate-ethanol, the RNA was resuspended in 16 to $21 \mu \mathrm{l}$ of sterile, $\mathrm{ddH}_{2} \mathrm{O}$ (Elga LabWater, Lane End Industrial Park, U.K.). RNA quantification was obtained using the NanoDrop 1000 spectrophotometer (Table 1).

\section{RT-PCR.}

A One-Step RT-PCR kit (Qiagen, Valencia, CA, U.S.A.) was used for the RT-PCR experiments conducted on the RNA extracted from the several samples. All the RNA samples were checked for DNA contamination through RT-PCR analyses conducted with specific tomato ribosomal primers (Table 2). Reactions were carried out in a final volume of $20 \mu$ l containing $4 \mu \mathrm{l}$ of $5 \times$ buffer, $1 \mu \mathrm{l}$ of $10 \mathrm{mM}$ dNTPs, $0.5 \mu \mathrm{l}$ of each primer $(1 \mu \mathrm{g} / \mu \mathrm{l}$, diluted $1: 10), 1 \mu \mathrm{l}$ of One-Step RT-PCR enzyme mix, and $1.5 \mu \mathrm{l}$ of total RNA (Table 1). The RNA from the second biological replicate was diluted 1:2 in the experiments using the different $L e P T$ primers. The samples were incubated for $30 \mathrm{~min}$ at $50^{\circ} \mathrm{C}$, followed by a 15 -min incubation at $95^{\circ} \mathrm{C}$. Amplification reactions (the primers and conditions are indicated in Table 2) were run for 40 cycles. The RT-PCR experiments were conducted on two independent biological samples and at least two technical replicates. The PCR products were separated by agarose gel electrophoresis in a Trisacetate-EDTA $0.5 \times$ buffer, stained with SYBRSafe, and visualized using a VersaDoc Imaging System (Bio-Rad Laboratories, CA, U.S.A.). The results presented are from the second biological replicate, except for GmHA5.

\section{PCR amplifications, cloning, and sequencing.}

The genomic DNA was extracted from $100 \mathrm{mg}$ of tomato leaves and from approximately $50 \mathrm{G}$. mosseae sporocarps using a DNA Plant Mini Kit (Qiagen). The PCR reactions were carried out in a final volume of $50 \mu \mathrm{l}$ containing $5 \mu \mathrm{l}$ of $10 \times$ buffer, $200 \mu \mathrm{M}$ each dNTP, $1 \mu \mathrm{M}$ of each primer, 50 to $100 \mathrm{ng}$ of genomic DNA, and 2 units of REDTaq DNA polymerase (Sigma-Aldrich). The PCR program was as follows: $95^{\circ} \mathrm{C}$ for $3 \mathrm{~min}$ ( 1 cycle), $92^{\circ} \mathrm{C}$ for $45 \mathrm{~s}, 45 \mathrm{~s}$ of annealing at the temperatures indicated in Table $2,72^{\circ} \mathrm{C}$ for $45 \mathrm{~s}$ (40 cycles), and $72^{\circ} \mathrm{C}$ for $5 \mathrm{~min}$ ( 1 cycle). The PCR product amplified from the tomato genomic DNA was extracted and purified using the PCR Extraction kit (Qiagen) and then directly sequenced. The DNA sequence analyses were performed with the Blastn software available at the National Center for Biotechnology Information.

\section{ACKNOWLEDGMENTS}

This work was supported by IPP-CNR, CEBIOVEM (D.M. 17/10/2003), and the Regione Piemonte (CIPE B74) projects. J. GómezAriza was supported by a fellowship of the European Leonardo da Vinci program.

\section{LITERATURE CITED}

Balestrini, R., and Bonfante, P. 2005. The interface compartment in arbuscular mycorrhizae: A special type of plant cell wall? Plant Biosyst. 139:8-15.

Balestrini, R., and Lanfranco, L. 2006. Fungal and plant gene expression in arbuscular mycorrhizal symbiosis. Mycorrhiza 16:509-524.

Benedetto, A., Magurno, F., Bonfante, P., and Lanfranco L. 2005. Expression profiles of a phosphate transporter gene (GmosPT) from the endomycorrhizal fungus Glomus mosseae. Mycorrhiza 15:620-627.

Bonfante, P. .2001. At the interface between mycorrhizal fungi and plants: The structural organization of cell wall, plasma membrane and cytoskeleton. Pages 45-61 in: The Mycota IX. K. Esser and B. Hock, eds. Springer-Verlag, Berlin, Heidelberg.

Bucher, M. 2007. Functional biology of plant phosphate uptake at root and mycorrhiza interfaces. New Phytol. 173:11-26.

Damar, P., Brunner, S., Person, B.L., Amrhein, N., and Bucher, M. .1998. Functional analysis and cell-specific expression of a phosphate transporter from tomato. Planta 206:225-233.

Day, R. C., Grossniklaus, U., and Macknight, R. C. 2005. Be more specific! Laser-assisted microdissection of plant cells. Trends Plant Sci 10:397-405.

Day, R. C., McNoe, L. A., and Macknight, R. C. 2006. Transcript analysis of laser microdissected plant cells. Technical focus, Physiol. Plantarum 129:267-282

Genre, A., and Bonfante, P. 2005. Building a mycorrhizal cell: How to reach compatibility between plants and arbuscular mycorrhizal fungi. J. Plant Interact. 1:3-13.

Genre, A., Chabaud, M., Timmers, T., Bonfante, P., and Barker, D. G. 2005. Arbuscular mycorrhizal fungi elicit a novel intracellular apparatus in Medicago truncatula root epidermal cells before infection. Plant Cell 17:3489-3499.

Gianinazzi-Pearson, V., Smith, S. E., Gianinazzi, S., and Smith, F. A 1991. Enzymatic studies on the metabolism of vesicular-arbuscular mycorrhizas: Is $\mathrm{H}^{+}$-ATPase a component of ATP-hydrolysing enzyme activities in plant-fungus interfaces? New Phytol. 117:61-74

Glassop, D., Smith, S. E., and Smith, F. W. 2005. Cereal phosphate transporters associated with the mycorrhizal pathway of phosphate uptake into roots. Planta 222:688-698.

Güimil, S., Chang, H.-S., Zhu, T., Sesma, A., Osbourn, A., Roux, C., Ioannidis, V., Oakeley, E. J., Docquier, M., Descombes, P., Briggs, S. P., 
and Paszkowski, U. 2005. Comparative transcriptomics of rice reveals an ancient pattern of response to microbial colonization. Proc. Natl. Acad. Sci. U.S.A. 102:8066-8070.

Harrison, M. J. 1999. Molecular and cellular aspects of the arbuscular mycorrhizal symbiosis. Annu. Rev. Plant Physiol. Plant Mol. Biol. 50:361365 .

Harrison, M. J. 2005. Signaling in the arbuscular mycorrhizal symbiosis. Annu. Rev. Microbiol. 59:19-42.

Harrison, M. J., Dewbre, G. R., and Liu, J. 2002. A phosphate transporter from Medicago truncatula involved in the acquisition of phosphate released by arbuscular mycorrhizal fungi. Plant Cell 14:2413-2429.

Hewitt, E. J. 1966. Sand and Water Culture Methods Used in the Study of Plant Nutrition. Commonwealth Agriculture Bureaux Farnhan Royal, Bucks, U.K.

Hohnjec, N., Vieweg, M. F., Puhler, A., Becker, A., and Küster, H. 2005. Overlaps in the transcriptional profiles of Medicago truncatula roots inoculated with two different Glomus fungi provide insights into the genetic program activated during arbuscular mycorrhiza. Plant Physiol. 137:1283-1301.

Inada, N., and Wildermuth, M. C. 2005. Novel tissue preparation method and cell-specific marker for laser microdissection of Arabidopsis mature leaf. Planta 221:9-16.

Javot, H., Pumplin, N., and Harrison, M. J. 2007a. Phosphate in the arbuscular mycorrhizal symbiosis: Transport properties and regulatory roles. Plant Cell Environ. 30:310-322.

Javot, H., Penmetsa, R. V., Terzaghi, N., Cook, D. R., and Harrison, M. J. 2007b. A Medicago truncatula phosphate transporter indispensable for the arbuscular mycorrhizal symbiosis. Proc. Natl. Acad. Sci. U.S.A. 104:1720-1725.

Jiang, K., Zhang, S., Lee, S., Tsai, G., Kim, K., Huang, H., Chilcott, C., Zhu, T., and Feldman L. J. 2006. Transcription profile analyses identify genes and pathways central to root cap functions in maize. Plant Mol. Biol. 60:343-363.

Karandashov, V., and Bucher, M. 2005. Symbiotic phosphate transport in arbuscular mycorrhizas. Trends Plant Sci. 10:22-29.

Kosuta, S., Chabaud, M., Lougnon, G., Gough, C., Denarie, J., Barker, D. G., and Becard, G. 2003. A diffusible factor from arbuscular mycorrhizal fungi induces symbiosis-specific MtENOD11 expression in roots of Medicago truncatula. Plant Physiol. 131:952-962.

Liu, C., Muchhal, U. S., Uthappa, M,, Kononowicz, A. K., and Raghothama, K. G. 1998. Tomato phosphate transporter genes are differentially regulated in plant tissues by phosphorus. Plant Physiol. 116:91-99.

Liu, J., Blaylock, L. A., Endre, G., Cho, J., Town, C. D., VandenBosch, K. A., and Harrison, M. J. 2003. Transcript profiling coupled with spatial expression analyses reveals genes involved in distinct developmental stages of the arbuscular mycorrhizal symbiosis. Plant Cell 15:2106-2123.

Maeda, D., Ashida, K., Iguchi, K., Chechetka, S. A., Hijikata, A., Okusako, Y., Deguchi, Y., Izui, K., and Hata S. 2006. Knockdown of an arbuscular mycorrhiza-inducible phosphate transporter gene of Lotus japonicus suppresses mutualistic symbiosis. Plant Cell Physiol. 47:807-817.

Nagy, R., Karandashov, V., Chague, V., Kalinkevich, K., Tamasloukht, M.,
Jakobsen, I., Levy, A. A., Amrhein, N., and Bucher, M. 2005. The characterization of novel mycorrhiza-specific phosphate transporters from Lycopersicon esculentum and Solanum tuberosum uncovers functional redundancy in symbiotic phosphate transport in solanaceous species. Plant J. 42:236-250.

Navazio, L., Moscatiello, R., Genre, A., Novero, M., Baldan, B., Bonfante, P., and Mariani, P. 2007. A diffusible signal from arbuscular mycorrhizal fungi elicits a transient cytosolic calcium elevation in host plant cells. Plant Physiol. 144:673-681.

Nelson, T., Tausta, S. L., Gandotra, N., and Liu, T. 2006. Laser microdissection of plant tissue: What you see is what you get. Annu. Rev. Plant Biol. 57:181-201.

Paszkowski, U., Kroken, S., Roux, C., and Briggs, S. P. 2002. Rice phosphate transporters include an evolutionarily divergent gene specifically activated in arbuscular mycorrhizal symbiosis. Proc. Natl. Acad. Sci. U.S.A. 99:13324-13229.

Ramsay, K., Jones, M. G. K., and Wang, Z. 2006. Laser capture microdissection: A novel approach to microanalysis of plant-microbe interactions. Mol. Plant Pathol. 7:429-435.

Rausch, C., Daram, P., Brunner, S., Jansa, J., Laloi, M., Leggewie, G., Amrhein, N., and Bucher, M. 2001. A phosphate transporter expressed in arbuscule-containing cells in potato. Nature 414:462-466.

Reinhardt, D. Programming good relations-development of the arbuscular mycorrhiza symbiosis. Curr. Opin. Plant Biol. 10:98-105.

Requena, N., Breuninger, M., Franken, P., and Ocón, A. 2003. Symbiotic status, phosphate, and sucrose regulate the expression of two plasma membrane $\mathrm{H}^{+}$-ATPase genes from the mycorrhizal fungus Glomus mosseae. Plant Physiol. 132:1540-1549.

Rosewarne, G., Barker, S. J., Smith, S. E., Smith, F. A., and Schachtman, D. P. 1999. A Lycopersicon esculetum phosphate transporter (LePT1) involved in phosphorus uptake from a vesicular-arbuscular mycorrhizal fungus. New Phytol. 144:507-516.

Smith, S. E., and Smith, F. A. 1990. Structure and function of the interfaces in biotrophic symbioses as they relate to nutrient transport. New Phytol. 114:1-38

Smith, S. E., Smith, F. A., and Jakobsen, I. 2003. Mycorrhizal fungi can dominate phosphate supply to plants irrespective of growth responses. Plant Physiol. 133:16-20.

Tang, W., Coughlan, S., Crane, E., Beatty, M., and Duvick, J. 2006. The Application of laser microdissection to in planta gene expression profiling of the maize anthracnose stalk rot fungus Colletotrichum graminicola. Mol. Plant-Microbe Interact. 19:1240-1250.

Trouvelot, A., Kough, J. L., and Gianinazzi-Pearson, V. 1986. Mesure du taux de mycorhization VA d'un système radiculaire. Recherche de méthodes d'estimation ayant une signification fonctionnelle. Pages 217-221 in: Mycorrhizae: Physiology and Genetics. V. GianinazziPearson and S. Gianinazzi, eds. INRA Press, Paris.

van Tuinen, D., Jaquot, E., Zhao, B., Gollotte, A., Gianinazzi-Pearson, V. 1998. Characterization of root colonization profiles by a microcosm community of arbuscular mycorrhizal fungi using 25S rDNA-targeted nested PCR. Mol. Ecol. 7:879-887. 